\begin{tabular}{|r|}
\hline ANGIES \\
NEW PERSPECTIUE5 \\
ANGLOPHINE WTRLD \\
\hline
\end{tabular}

\title{
Angles
}

New Perspectives on the Anglophone World

$6 \mid 2018$

Experimental Art

\section{New Old Forms: Djuna Barnes's and Virginia Woolf's Return to the Archaic as Experimental Modernist Form}

\section{Elaine Hsieh Chou}

\section{(2) OpenEdition \\ Journals}

Electronic version

URL: https://journals.openedition.org/angles/1008

DOI: $10.4000 /$ angles. 1008

ISSN: 2274-2042

Publisher

Société des Anglicistes de l'Enseignement Supérieur

\section{Electronic reference}

Elaine Hsieh Chou, "New Old Forms: Djuna Barnes's and Virginia Woolf's Return to the Archaic as Experimental Modernist Form", Angles [Online], 6 | 2018, Online since 01 April 2018, connection on 08 June 2022. URL: http://journals.openedition.org/angles/1008; DOI: https://doi.org/10.4000/angles. 1008

This text was automatically generated on 8 June 2022.

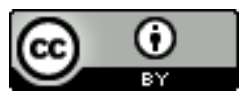

Angles est mise à disposition selon les termes de la Licence Creative Commons Attribution 4.0 International. 


\title{
New Old Forms: Djuna Barnes's and Virginia Woolf's Return to the Archaic as Experimental Modernist Form
}

\author{
Elaine Hsieh Chou
}

\section{The Uncensored Texts of 1928}

11928 was a tumultuous year for literature in the English-speaking world. D.H. Lawrence's Lady Chatterley's Lover was printed privately in Italy. Compton Mackenzie's Extraordinary Women featured lesbians on the island of Capri. Radclyffe Hall's The Well of Loneliness was embroiled in a highly publicized obscenity trial. The latter was banned not because it featured explicit scenes but because it earnestly asked for lesbians or "inverts" to be accepted in society. Amidst this commotion, two other controversial texts published that same year somehow went unscathed: Virginia Woolf's Orlando and Djuna Barnes's Ladies Almanack, which are both centered around same-sex love and the arbitrariness of gender - shocking notions in 1928. Although they are experimental in their form and content, neither are remembered as being so. In all of Woolf's oeuvre, Orlando is seen as her unserious, frivolous work and Ladies Almanack has never even been considered part of the modernist canon, let alone a groundbreaking work. Why were two highly experimental works never thought of as such?

2 Perhaps we should recall that in and around 1928, "High Modernism" was still at its peak. Just the year before, Woolf had published To the Lighthouse; Dorothy Richardson, Oberland; James Joyce, sections of Finnegans Wake. In 1928, T.S. Eliot released parts of "Ash Wednesday"; Ezra Pound, a draft of "The Cantos." These works are not only remembered for being experimental, they have become examples of what defined experimental writing during modernism. ${ }^{1}$ Although Joyce, Eliot and Pound liked to borrow from Greek myth and Old English, the un-borrowed language they employed 
remained firmly stuck in the early $20^{\text {th }}$ century. Their experimentalism was entirely predicated on the formal structures and typography that had become popular within literary circles. Orlando and Ladies Almanack, on the other hand, embraced the florid and descriptive language of bygone eras, borrowing from the Elizabethan and the Rabelaisian. Both texts are also extremely funny-a rarity in "High Modernist" literature. Because of this, these texts were not heralded as new or experimental literature upon their publication.

3 This paper seeks to explore a widespread anomaly prevalent during the era of modernism, which valued only experimental form and disregarded experimental content. Modernism's habit of valuing a strict set of art forms above all others had longlasting repercussions: not only did it dictate what was worth including in the English canon, it diminished and discarded "female" forms of writing. If experimentalism is defined by that which deviates from contemporaneous work, Orlando and Ladies Almanack were undeniably experimental, both for their renewal of an "archaic" textuality that celebrated rather than repressed language and for their overturning of stable sexual identities. I argue that the choice to use humor, the whimsical and the playful, far from being outdated styles belonging only to the Restoration period, were experimental, sociopolitical choices inseparable from the provocative subject-matter of both texts. Thus, choosing to cultivate an aesthetics of the "old-fashioned" was necessarily political. I aim to uncover why writing about unorthodox desire required an alternative language or a renewal of prior literature.

4 Arguably, Woolf and Barnes moved within a limited circle of writers and thinkers, certainly one restrained by English and American contexts. But the stakes articulated by Orlando and Ladies Almanack extend beyond this small circle and are representative of an age-old belief: that experimentalism is defined by what is "new," with the concept of "newness" being deeply rooted in a celebration of the masculine and a denigration of the feminine. By recognizing the experimental and subversive quality of these two works, we initiate a discourse that goes beyond "High Modernism" into its peripheral, hybrid spaces. If we consider Orlando and Ladies Almanack not as oddities in the modernist narrative but as quintessentially modernist, we must rearticulate how the "new" is not necessarily experimental and how the "archaic" is not necessarily uninventive. Although these two works might seem like outliers in an otherwise seamless modernist discourse, they must still be considered modernist texts and experimental in their own right.

\section{Where "Experimental" Converges with "Modernist"}

5 How the experimental became diametrically opposed to the traditional is historically linked to modernist definitions of the experimental. According to The Routledge Companion to Experimental Literature:

[Experiment literature] lays everything open to challenge, reconceptualization and reconfiguration. Experimentation makes alternatives visible and conceivable, and some of these alternatives become the foundations for future developments, whole new ways of writing [...]. Experiment is one of the engines of literary change and renewal; it is literature's way of reinventing itself. (Bray et al. 2012:1)

6 In this standard definition, newness and future-forward thinking are inherent in all experimental literature. These themes have largely defined the period of the 1900s- 
1940s, so much so that the word "modernist" has become synonymous with the word "experimental." The Routledge Companion goes on to explain that "Many of the general features, and even some of the specific practices, of experimental literature of the second half of the century were anticipated by the avant-garde groups of the period from just before the Great War until the immediate aftermath of World War II, the epoch of the great isms of the early twentieth century" (Bray et al. 2012: 4). This conflation of terms - modernist and experimental - would secure the place of a few selective works in our collective memory, consigning others to obscurity.

Modernist anthologies, too, like to refer to World War I as the catalyst for the dramatic form-breaking that ensued in the early $20^{\text {th }}$ century. In this version of modernist literature, when Western society became fragmented and broken, poetry followed suit: the sonnet turned into free verse, words left their textual placeholders to travel across the page in disjointed typography or non-existent punctuation. The coherent and chronological narrative gave way to the opaque and the absurd. We are reminded of Ezra Pound's call for all artists to "make it new." Modernism has long been associated with a "dramatic break from the past" (Schoenbach 2012: 4) and descriptions of this period fall back on negative words such as collapse, destruction, dissolution, disintegration, crisis, etc. (Schoenbach 2012: 4). In The Modernist Papers, Frederic Jameson departs from the theme of "the new" but nonetheless highlights how "conventionality" and "kitsch" were anathema to modernism:

What drives modernism to innovate is not some vision of the future or the new, but rather the deep conviction that certain forms and expressions, procedures and techniques, can no longer be used, are worn out or stigmatized by their associations with a past that has become conventionality or kitsch, and must be creatively avoided. (Jameson 2007: 5)

Elitism was thus inextricable from the monolithic and selective discourse that was High Modernism.

The advent of the avant-garde and its formalist, military undertones add another facet to what "experimental" implied. As Peter Burger has explored, shocking the public was at the core of the avant-garde (Burger 1984). Shocking meant anything besides what was already known; it certainly did not include tradition or bygone concepts. Victorian literature was thus frowned upon and any pleasurable reading automatically became a detested form of unintelligent "mass culture." In his influential text Modernisms: A Literary Guide, Peter Nicholls explains that "The contempt for forms of popular culture which would determine some of the avant-garde positions of the later modernism has its roots in the nineteenth-century responses to the growth of the literary market" (Nicholls 2009: 12). Popularity in the form of financial payoff had become stigmatized.

This version of modernism as a desolate "waste land" takes precedence in society's collective memory and remains the version we believe is worth teaching, ${ }^{2}$ none of which is an accident:

[T] he most vocal critics of mass culture were in fact the pioneers of universitybased English programs, British Modernist critics, whose foundation for the study of literature was based on a repudiation of mass culture and mass-cultural consumptive practices. (Pease 2011: 197-8)

11 Cambridge scholars, along with T.S. Eliot, "created the intellectual basis that English literature studies followed in Britain [...]. Not only were they the first, Modernist critical practices were the formative practices of English literary criticism produced within the university" (Pease 2011: 201). Modernism, conceived as a narrow-minded 
vision of experimentalism, was in fact institutionalized within and through universities, the birthplace of the literary canon. As Suzanne Clark put it so aptly, "High modernism meant that the works of a few male writers stood for a whole period of literary history" (Clark 1991: 34-5). To this Shari Benstock adds "modernism constructed itself on a political agenda of exclusion - the exclusion of the Other" (Benstock 1994: 100). The irony is not amiss here: although the avant-garde considered themselves as being on the margins of mainstream art, they did not recognize that they themselves took part in marginalization: "avant-garde movements have willfully chosen their marginal position - the better to launch attacks at the center - whereas women have more often than not been relegated to that position" (Suleiman 2014: 151). This double standard of the avant-garde may explain why some of the most experimental works of the modernist period remain unknown and unstudied.

Furthermore, conceptions of the avant-garde and the experimental were gendered by nature. Although there are numerous instances of "male" qualities trumping "female" qualities in literature, suffice it to say that "[i]nstances of Modernist advocacy of firm, hard, dry, terse, classical masculinity, over and against the messy, soft, vague, flowery, effusive, adjectival femininity of the late Victorians, abound, and instances of male Modernist antifeminism and misogyny are legion" (DeKoven 2011: 214). From fiction to essays to manifestos, the gatekeepers of what qualified as art had also decided that good art was inherently male. Pound, considered a "father" of modernism, believed that true genius was born in the male reproductive system. He postulated that "it is more than likely that the brain itself, is [...] only a sort of great clot of genital fluid held in suspense or reserve" (qtd. in Burke 1987: 103-4). Thinking turns into a creative act via "the phallus or spermatozoid charging, head-on, the female chaos" (Burke 1987: 104). Even at the biological level, women were stripped of creative agency.

Modernism's fear of sentimentality and all its connotations is not unrelated to these misogynist agendas: "The term sentimental makes a shorthand for everything modernism would exclude, the other of its literary/non-literary dualism" (Clark 1991: 9). This "feminization of culture as content" meant that modernism got away with its "questionable exclusions" and "its most notoriously reactionary violence" (9), thereby "revers[ing] the increasing influence of women's writing" and the importance of its evolution (1). Gendered, modernism associated women with "the mass" and its productions became "objects of critical disdain" (5). These ideas were bound up in what constituted experimental writing:

Modernism is [...] stabilized by a system of gendered binaries: male / female, serious / sentimental, critical / popular. Upsetting the system - as women do - introduces an instability and reveals the contradictions. As we acknowledge the contributions of women, we see that modernism was both revolutionary and reactionary; the sentimental was both banal and transgressive. (Clark 1991: 8)

Written off as "feminine," Orlando and Ladies Almanack stood little chance as being recognized as "serious" (code for "masculine") literature.

What did it mean that those producing "the only" experimental work were then deeming it as such? They were simultaneously defining and upholding a self-made standard within a closed circle of cultural production and critique. This phenomenon provides useful insight into why Orlando and Ladies Almanack did not create shockwaves in 1928 in spite of their incredibly experimental, incredibly taboo content. No matter their content, their form ostensibly belonged to the past (and according to "High 
Modernism," form dictated experimentalism above all else). At the same time, these two novels do not easily fit into any single interpretative mold because they are not sentimental in tone, nor are they examples of mass-produced entertainment. They were written by two women who moved in the literary circles of Bloomsbury and Parisian salons and who considered themselves among those writers doing critical, experimental work. In the two following sections, I will postulate why Orlando and Ladies Almanack were both misread until nearly a half a century after their publication.

\section{Orlando: Metafiction and Performing Gender} what kind of novel it would be. At the outset Woolf revealed, "I am writing Orlando half in a mock style very clear \& plain, so that people will understand every word. But the balance between truth \& fantasy must be careful" (Woolf 1980: 162). Later she explained, "The truth is I expect I began it as a joke, \& went on with it seriously" (185). This ambivalence about just how explicit Orlando could be persisted until its completion, when Woolf thought that it "may fall between two stools, be too long for a joke, \& too frivolous for a serious book" (177). Even though she referred to her novel a "lark" and a "writer's holiday," she remained determined to "revolutionise biography overnight" (Woolf 1977: 429). 1975: 222), an "orgy of romance" (225), "a wonderful phantasmagoria," "a kind of inspired joke" (235), "tongue in her cheek" (235) with "an important element of 'spoof" (235). Critics invented an explanation for Woolf's sudden departure in style by deploying a lexicon of the improbable in order to discredit her novel. J.C. Squire writes off Orlando in a few swift sentences:

This book is a very pleasant trifle and will entertain the drawing-rooms for an hour: a suitable companion for the jade carving and the painted snuff-boxes. But I think that even of its kind it is not in the first order. Even a trifle, to be excellent, must have enthusiasm behind it. This book, one feels, was conceived frivolously and chancily. (quoted in Majumdar and McLaurin 1975: 229)

Cleveland Chase's review is even harsher, claiming that the theme of Orlando is "for a Victor Hugo, not for Mrs Woolf... Her best novel, To the Lighthouse raised my hopes for her. Orlando has dashed them and they lie in iridescent fragments at my feet" (quoted in Majumdar and McLaurin 1975: 233). The reference to Hugo is intended to make Woolf's work appear outdated. Chase had "horrid doubts" about Woolf being one of "the only important innovating novelists" and concluded that "only Joyce is [...] sure of a place in the history of the development of the novel" (234). In none of these reviews is the novel's subversive and progressive themes mentioned let alone praised. They all effectively dismiss Woolf's novel as glib and frivolous.

The only review written by a woman, Helen MacAfee for The Yale Review, takes up the defense of Orlando:

It is the right and the nature of the artist to renew the forms of expression inherited from great predecessors by impressing upon them his own intense being. Mrs Woolf, who has chosen fiction as her chief literary medium, has from the first shown herself impatient of the old categories, and now in her latest novel she declares her independence openly in the subtitle, 'a biography.' (quoted in Majumdar and McLaurin 1975: 237) 
affee intuits the experimental nature of Orlando that aimed to "renew," to "revolutionise," a sentiment shared by Woolf's husband. Woolf wrote in her diary that Leonard "takes Orlando more seriously than I had expected. Thinks it in some ways better than The Lighthouse; about more interesting things, \& with more attachment to life, \& larger" (Woolf 1980: 185). But years later, even in contemporary surveys of Woolf's work, Orlando is left out of her œuvre. As Sherron E. Knopp has noted, "Those who admire the book hasten to admit that it is only a minor interlude amidst more serious acts of creation" (1988: 25). One example Knopp cites is Mitchell Leaska who in 1977, “omitted [Orlando] from The Novels of Virginia Woolf: From Beginning to End. The few critics who treat the novel sympathetically and at any length locate its claim to serious consideration elsewhere than in the sexual politics that are its raison d'être" (25).

And yet, Orlando was perhaps the first English novel to explicitly separate gender from selfhood. Orlando is written in the third-person from the point of view of a biographer who attempts to recount the wondrous life of Orlando, who was born a man until his thirtieth year when he inexplicably wakes up a woman: "Orlando had become a woman -there is no denying it. But in every other respect, Orlando remained precisely as he had been. The change of sex, though it altered their future, did nothing whatever to alter their identity" (Woolf 1973: 133). The novel's sexual politics is not cloaked in difficult language. During his 300 years of life, Orlando's love of women, or at least a certain woman (Sasha), remains constant: "though she herself was a woman, it was still a woman she loved" (154). He manipulates his gender through sartorial performance by simply trying on and taking off different clothes, realizing that, "Vain trifles as they seem, clothes have, they say, more important offices than to merely keep us warm. They change our view of the world and the world's view of us" (179). Orlando laments how his physical capacity is hampered by heavy and restricting dresses. He discovers he was unquestionably granted certain rights as a man and then, for no logical reason, stripped of these rights when he becomes a woman. As a lady, she is ushered into a society where her role is to nod and smile, to not show too much conviction or intelligence. The narrator wryly notes, "As long as she thinks of a man, nobody objects to a woman thinking" (268), one example out of many similar remarks. Towards the end of novel, Orlando feels the ticking of the societal clock so forcefully that almost against her will she marries and quite literally finds a child in her arms.

Towards the end of the novel, however, Orlando discovers that her husband Marmaduke Bonthrop Shelmerdine was also performing gender: "You're a woman, Shel!" to which Shel responds, "You're a man, Orlando!" (252). Heterosexual marriage thus transforms into its disavowed other. Like Judith Butler would argue years later in Gender Trouble, Woolf understood that gender is a performance. According to Butler:

[A]cts, gestures, enactments, generally construed, are performative in the sense that the essence or identity that they otherwise purpose to express are fabrications manufactured and sustained through corporeal signs and other discursive means. That the gendered body is performative suggests that it has no ontological status apart from the various acts which constitute its reality. (Butler 1990: 185)

Throughout Orlando, s/he only performs male or female - we are never told what sex Orlando is born with. The fact that Orlando is able to switch genders, ("she seemed to vacillate; she was man; she was woman" [Woolf 1973: 152]) was a provocative statement about how biological sex does not equate gender identity. Going even further, Woolf seems to argue that embracing a more androgynous conception of the self is fulfilling 
and beneficial: "nor can there be any doubt that [Orlando] reaped a twofold harvest by this device; the pleasures of life were increased and its experiences multiplied" (211).

The form of the novel, too, effectively undid biography just as Woolf claimed she would. As she was writing, Woolf wondered in her diary "What is obscenity? What is literature? What is the difference between the subject and the treatment?" (Woolf 1980: 207). Orlando is born during the reign of Queen Elizabeth and lives on into Woolf's present day. In fact, in a bold metatextual move, the biography ends the day the book is published. It was entirely inspired by and dedicated to Woolf's friend and lover Vita Sackville-West, who could not inherit her ancestral home Knole because of her sex. Woolf takes up her cause in Orlando and "gives" Knole to Sackville-West permanently through the act of writing. ${ }^{3}$ The reader embarks on a novel that claims it is a biography, only to discover Orlando is a fictional character, only to discover that he is based on a woman who very much exists. The text is experimentally metafictional since it acknowledges its own fictiveness but also incorporates a number of true-to-life facts. The textual seams "show" and Woolf makes no effort to hide them, in the sense that she does not smooth over the text's many discrepancies. In fact, the first edition was printed with oil paintings and photographs purported to document Orlando's life but included actual photos of Vita as a child and adult (Figure 1). This flouting of the usual author-reader pact was of great confusion to most critics. A fictitious male/female character portrayed through photographs of a very real, living woman? Serious literature was not allowed to have so much fun!

Figure 1: Extract from Virginia Woolf, Orlando: A Biography. New York: Crosby Gaige, 1928

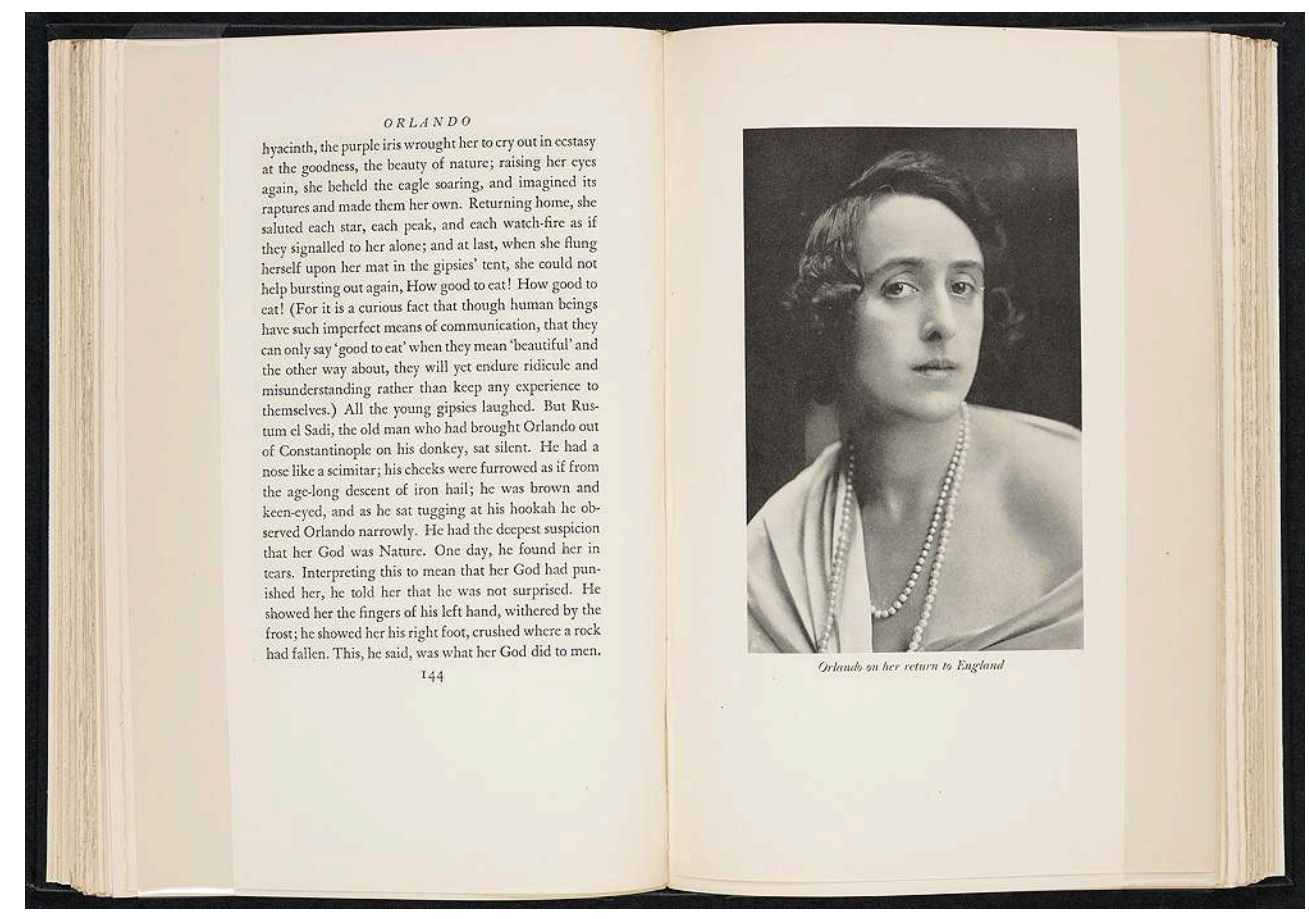

Page 145 shows a photograph purportedly of Orlando.

Source: https://www.smith.edu/libraries/libs/rarebook/exhibitions/penandpress/case11a.htm

The burning question is why did absolutely no review discuss Orlando's radical refutation of gender norms or its undoing of biography and fiction. The answer lies in two phenomena discussed earlier: the novel's popularity and its "archaic" form: Knopp 
informs us "that the book sold twice as many copies in six months as To the Lighthouse had in a year" and was considered by Leonard as "the turning point in her career" (Knopp 1988: 143). After its success, Woolf herself remarked, "I think I may say that I am now among the well-known writers" (Wool 1980: 201). It was her first financial success, yet it was received as the least of her literary successes. Its popularity nullified its esoteric potential.

As for the novel's archaic form, a brief glance at the first pages of Orlando tells us that Woolf's language took on a different tone from her earlier works:

Happy the mother who bears, happier still the biographer who records the life of such a one! Never need she vex herself, nor he invoke the help of novelist or poet. From deed to deed, from glory to glory, from office to office he must go, his scribe following after, till they reach whatever seat it may be that is the height of their desire. (Woolf 1973: 14)

The syntax and diction used throughout the novel is reminiscent of an earlier era in writing, notably Elizabethan; this should come as no surprise considering the novel's initial time frame, though the style of language remains consistent throughout. Critics today commonly agree that the fantastical nature of the novel and its archaic language were Woolf's methods of protecting the novel from censorship. She closely followed Hall's The Well of Loneliness controversy and was prepared to testify at the obscenity trial. Although in the end she did not testify because of pressure from the Bloomsbury group, one cannot help but wonder if the outcome of the trial encouraged her to lean more towards the un-incriminating fantastical. But I would also argue that her reclamation of archaic language is anything but uninventive, unoriginal or unexperimental.

\section{Ladies Almanack: A Homocentric and Intermedial Found Object}

If Orlando was an anomaly for 1928, imagine the odds of a similarly "archaic" book produced that same year. Djuna Barnes originally had trouble finding a publisher for her "chapbook." In the end, Ladies Almanack was printed by Maurice Darantier in Dijon, the same publisher as Ulysses after Sylvia Beach's first publication. Its only print run was relatively small, some 1,050 copies, which may explain why no (discoverable) contemporary reviews of Ladies Almanack appeared after its initial publication. Unlike Orlando's financial success, Ladies Almanack gained little revenue and was sold in the streets of Paris to raise money for Thelma Wood's spinal surgery, who was Barnes's lover at that time. Although in 1928 there were no comparative reviews of Orlando and Ladies Almanack, Alfred Kazin considered the two writers side-by-side in The New York Times Book Review in 1937:

It was Virginia Woolf who delivered that challenge in one of her numerous attacks on realism in the novel, but Miss Barnes has gone beyond Mrs. Woolf's practice of her own theory. For Miss Barnes is not even concerned with the immediate in time that fascinated the stream-of-consciousness novelists. (qtd. in Marcus 1991: 197)

She was furiously interested in the past and its intersections with the present, as was indeed Woolf.

Just as Orlando was born from a biographical standpoint, Ladies Almanack blurs fiction with reality. Self-labeled a "slight satiric wigging," Ladies Almanack is a roman à clef 
centered on Natalie Clifford Barney's Paris salon, featuring Barney as the protagonist "Dame Evangeline Musset," in addition to writers Radclyffe Hall, Mina Loy, Lady Una Troubridge, Janet Flanner, Dolly Wilde, Romaine Brooks and Solita Solano. Compared to Orlando, it features explicit descriptions of the lesbian milieu in Paris but one has to be able to read through numerous puns and private jokes to understand just how bawdy Ladies Almanack really is. The details of lesbian lovemaking is disguised in archaic language: Musset, who was "wide famed for her Genius at bringing up by Hand, and so noted and esteemed for her Slips of the Tongue" (Barnes 1972: 9), fondly tells a story that boasts her expertise with the female anatomy: "I recall one dear old Countess who was not be confined until I, fervid with Truth, has finally so floored her in every capacious Room of that dear ancestral Home, that I knew to a Button, how every Ticking was made!" (34-5). The text spins on a homocentric axis: every woman is "turnable." Dame Musset makes it her mission to "turn" all women and is unerringly successful (Barney was a famous lover and seduced several married women). Her sexual prowess is even immortalized when, after she dies and her body is cremated, "all had burned but the Tongue, and this flamed, and would not suffer Ash," and her admirers sit upon the eternal flame of her tongue (84). Like Orlando, Dame Musset is a blend of masculine and feminine: at her birth, she "came forth an Inch or so less than" a boy (2) and when her father expresses his disappointment that she was born a girl, she replies: "Am I not doing after your very Desire, and is it not the more commendable, seeing that I do it without the Tools for the Trade, and yet nothing complain?" (2). In the world of Ladies Almanack, female desire is embedded in mimesis: the ideal relationship is "Bosom to Bosom, Braid to Braid, Womb to Womb!" (19) and while "A man's love is built to fit Nature," a "Woman's is a Kiss in the Mirror" (23). The outlier in their coterie is Patience Scalpel (Mina Loy) because she prefers men, although she makes the mistake of supposing that, "she herself, though all Thumbs at the business and an Amateur, never having gone so much as a Nose-length into the matter, could mean as much to a Woman as another" (50). Sexuality is presented as fluid and changeable, similar to gender in Orlando. But Barnes goes even further: the Almanack decries romantic love, monogamy and hypocritical middle-class sensibilities on marriage and lust. Hall's character (Tilly Tweed-in-Blood) advocates for same-sex marriage: "Just because woman falls, in this Age, to Woman, does that mean that we are not to recognize Morals? What has England done to legalise these Passions? Nothing!" (19). An undisputed given in the text is the dangerous nature of patriarchy: in addition to decrying man's inability to please women, the narrator mocks man's desire to "medicalize" female desire. ${ }^{4}$ Indeed, at age ten Dame Musset was "deflowered by the Hand of a Surgeon" (24) and her "turning" of women is her vindication: "I am my Revenge!" (25). But Lady Buck-and-Balk goes one step further, declaring "would that we could do away with Man altogether!" (24). Moreover, Barnes rewrites and invents religious myths about the fall of Lucifer, Jezebel and Sheba in order to render them more centrally feminine myths. "[T]he first Woman born with a Difference" (26) is hatched from an egg, not from the union of Adam and Eve. For these reasons and others, Ladies Almanack has been called "a radical critique of patriarchy" (Lanser 1979: 41) that effectively "legitimize[d] lesbian eroticism by taking it for granted" (Nair 2012: 78). But why did it take until 1979 for Ladies Almanack to receive critical attention as a groundbreaking text, to be finally recognized as "a linguistic and literary experiment" (Lanser 1979: 40, my emphasis)? 
Just as Orlando's form had barred the book from being received as experimental, so too did Ladies Almanack's form determine its status as decidedly un-modern. The beginning lines are no more of this age than they were a century ago:

NOW this be a Tale of as fine a Wench as ever wet Bed, she who was called Evangeline Musset and who was in her Heart one Grand Red Cross for the Pursuance, the Relief and the Distraction, of such Girls as in their Hinder Parts, and their Fore Parts, and in whatsoever Parts did suffer them most, lament Cruelly, be it Itch of Palm, or Quarters most horribly burning, which do oft occur in the Spring of the Year, or at those Times when they do sit upon warm and cozy Material [...] (Barnes 1972: 1).

Did Barnes, like Woolf may have, believe that an archaic, coded language would protect her from the judgmental censorship she saw her friend Hall undergo? The diction, syntax, capitalization, neologisms, archaisms and satirical puns are more consistent with the English Restoration than 1928's popular aesthetics of the time. The book is presented as an almanac, an ancient book form that records changes in the calendar, the weather, moon and sun. Ladies Almanack's chapters follow the astrological calendar. But it is also written as an antiquarian chapbook, popular during the $16^{\text {th }}$ century, which were medleys of different bits and pieces, from advice to popular ballads. In a similar vein, Barnes includes a song complete with musical bars, a poem and sidenotes in the margins. But the book is also a patchwork of many other forms: it "resembles the picaresque fable in structure, the mock epic in tone; it uses or parodies a host of forms including the saint's life, the ode, the prayer, the love song, the allegory, classical mythology, and Sacred Scripture itself" (Lanser 1979: 40). Barnes turned genre on its head with her collage-making, borrowing from different media to create a text that defies categorization.

Ladies Almanack is iconographic in the purest sense of the word. Barnes self-illustrated the book in the form of mock wood-cuts, drawing "baroque cherubs, ornate parodies of religious iconography, feminized zodiacs, and other emblems archaic and arcane (Figure 2). The result is a pastiche which defies generic classification" (Lanser 1979: 40). The interplay between text and image was quite commonplace before the $19^{\text {th }}$ and $20^{\text {th }}$ centuries but highbrow modernism frowned upon intermedial projects and artists; they valued "disciplinary purity" and favored a strict separation of the arts in a bid to endow literature with "an authority enjoyed by the sciences" (McDonald viii). As much as Cubist and Dadaist art seemed to collide with modernist poetry, High Modernism "militated against genuinely cross-disciplinary work"' (Elliott and Wallace 1994: 124). Barnes's illustrations give the Almanack a depth and complexity that go beyond the text in an acknowledgement of its material textuality. Image and text do not meld together but are juxtaposed in dialectic tension.

Ladies Almanack, with its refusal to acknowledge the year 1928 save for some "slips of the tongue," presents itself not as a new publication but as if it were an old relic accidentally discovered at a secondhand bookstore. Caselli describes it as both an "antiquarian object" and a "carefully crafted artefact" (Caselli 2009: 41, 44). Unlike other modernist works that heavily cite authors and works from the past, no other text devotes itself so entirely to the past. Ladies Almanack is thus experimental at the same level as Marcel's Duchamp's found object, upending assumptions about authorial control (the novel is signed by the pseudonym "A Lady of Fashion"). Caselli explains that "The almanac tradition thus provides this 1928 text with the means to resist the 
centrality of author and plot" (2009: 46). Individual authorship is fittingly erased in a text that takes female community as its very center.

Figure 2: Frontispiece of Djuna Barnes' 'The Ladies Almanack' (1928)

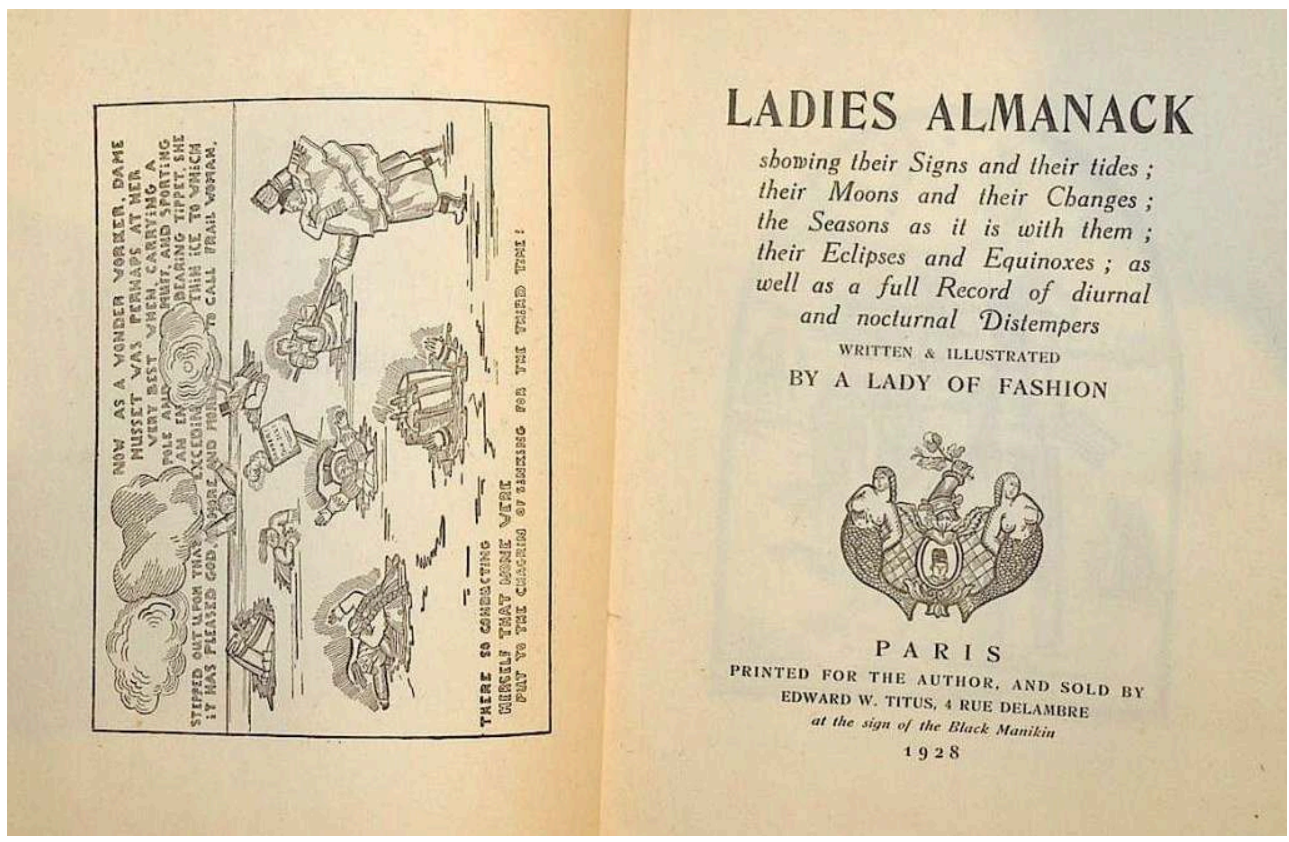

Source: http://jot101.com/2014/08/djuna-barnes-ladies-almanack-1928/

In addition to its antiquarian language and illustrations, the text is also exceedingly playful, its drawings round-figured and quaint-all of which give the book a simultaneously flat and three-dimensional quality, as if it were a children's book for adults. There was decidedly nothing else like it on the market. But Barnes was never given recognition for her ingenuity and her unique form of experimentalism despite writing prose and poetry unlike any other modernist writer. Her version of modernism was uniquely her own: a self-taught writer, she had an astonishing command of the English language. Sylvia Beach wrote that her writing, "with its strangeness and its melancholy note [...] did not resemble that of any other writer of her time" (1956: 112). Her style has been more closely aligned to Gothic literature or even fin-de-siècle decadence than the style of her peers; yet her politics were a century ahead of them. Paul West astutely points out that Barnes "wanted to undo all readers, to deflower them one way or another, to stop them from expecting fiction to behave like some wellbred social organism" (West 1990: 242). Barnes did not try to tame language, she let it roam uninhibited.

\section{Let the Women Play}

While Orlando was damned because of its popularity, Ladies Almanack was damned because of its obscurity. Their transgressive and subversive ideas were ignored not only because of the double standards of High Modernism but because, I believe, they posed too great a threat to societal norms. As it turns out, modernism was not as futurist or forward-looking as it claimed in spite of its furious "form-breaking." Woolf and Barnes lobbied for an anti-essentialist notion of gender and a separation of gender and sexual 
desire, notions which are hardly accepted today. Woolf and Barnes wanted to go beyond the restricting category of "lesbian" which they were both ambivalent about, preferring the term "Sapphic" instead. Their interest in exploring same-sex lives, both within and outside of the page, is also an interest in sameness as a concept, sameness as an exploration of the self through the other. "Modernism had mothers as well as fathers," DeKoven declared (2011: 213). In these texts written for other women (Vita Sackville-West and Thelma Wood) Woolf and Barnes were gesturing towards these maternal literary roots. Clark adds that "modernism invented an écriture féminine, a feminine writing which would rupture male conventions. But it did not make possible the appearance of a feminine subject within language" (Clark 1991: 7-8). The need to make room for a feminine subject was never more apparent than when Woolf sought out the "female sentence" in A Room of One's Own and developed it further in Three Guineas.

Why did Woolf and Barnes both decide to return to older forms of language as a way of saying something new (about women, about gender, about love) in 1928? Most critics would say it was for pragmatic reasons, to avoid censorship, and it is undeniable that Orlando and Ladies Almanack were not written in the same earnestness as The Well of Loneliness. Their formal movements were decisively un-transparent, usurping the reader at every turn; such textual manipulation was a method of controlling and diverting the reader's assumptions. But censorship seems too simple an answer. Orlando and Ladies Almanack's similarities include a return to nature (with Orlando's Romantic desire for nature as maternal, nurturing and inspirational) in addition to a return to a more pagan conception of the woman's body (the Almanack's structuring through the phases of the moon). I argue that Woolf and Barnes wanted to leave behind the dryness and hardness of highbrow modernism, not to return to the Elizabethan age but to revel in nostalgia for the frivolous, fantastical and the off-limits funny because, oddly enough, there was more freedom in the bawdiness of the pun and the endless possibilities of the impossible. Words had taken on a sterility in their time; because modernism took itself too seriously, criticism and high-minded elitism had become suffocating. Orlando and Ladies Almanack's language is fertile in more senses than one: for its multiplicity, joyous rapture and jouissance, its irreverence and laughter; for its symbolic creation of a lasting object between two women, which could not manifest itself physically through the act of pregnancy and birth. It was within the wild, yet safe, space of language that a woman could be anything: another sex, adventurous, glib, even immortal - she was free to experiment not just formally but thematically in an effort to discover what modernism meant to her.

\section{Canonical Revisions and Experimentalism}

To acknowledge Orlando and Ladies Almanack's place in experimental modernist literature would create reverberations throughout all literature that we consider experimental. Reinscription within the canon (or anti-canon) is not divorced from the political. Benstock points out, for example, that to acknowledge Woolf's bisexuality, scholars "would be forced to redefine modernism in ways that acknowledge its Sapphic elements" (Benstock 1994: 97) and to reckon with modernism's volatility, its unknowability - unsettling notions for all literary scholars and critics who have tried to give shape to an era. Benstock explains that 
[Sapphic texts] are difficult to place according to genre. Because they insist upon writing beyond the boundaries of our inherited critical traditions, readers have difficulty in knowing what to say [...]. Collectively, these texts are the 'dangerous symptoms' of a system that cannot tolerate difference. (Benstock 1994: 114) they fit into Eliot or Pound's modernist mold in an effort to justify their worth. The point is to reconsider such exclusionary standards altogether, to perhaps stop applying them to women writers they did not, could not, understand. The myth that modernism was about pure aesthetics is no longer sustainable because even though "Modernism practiced a politics of style, it denied that style had a politics" (Clark 1991: 5). To what extent is our collective obsession with experimental form (often at the expense of experimental content) founded in misogyny and elitism, steeped in fear of "mass culture," in a reluctance to democratize art? In the end, the standards that decided what was and was not experimental were arbitrarily dictated in 1928, as they still are today. The political nature of the experimental, and its far-reaching tentacles, shocks us into the realization that there is always more at stake than pure aesthetics when we call something "experimental."

\section{BIBLIOGRAPHY}

Barnes, Djuna. Ladies Almanack. New York: Harper \& Row, 1972.

Beach, Sylvia. Shakespeare and Company. New York: Harcourt, 1956.

Benstock, Shari. "Expatriate Sapphic Modernism: Entering Literary History.” Rereading

Modernism: New Directions in Feminist Criticism. Lisa Rado, ed. New York: Garland Publishing, Inc., 1994.

Bray, Joe, Alison Gibbons and Brian McHale, eds. The Routledge Companion to Experimental Literature. New York: Routledge, 2012.

Burger, Peter. Theory of the Avant-Garde. Minneapolis: U. of Minnesota P., 1984.

Burke, Carolyn. "Getting Spliced: Modernism and Sexual Difference.” American Quarterly vol. 39, No.1 (Spring 1987): 98-121. DOI: 10.2307/2712632

Butler, Judith. Gender Trouble: Feminism and the Subversion of Identity. New York: Routledge, 1990.

Caselli, Daniela. Improper Modernism: Djuna Barnes's Bewildering Corpus. Burlington: Ashgate Publishing Limited, 2009.

Clark, Suzanne. Sentimental Modernism: Women Writers and the Revolution of the Word. Bloomington: Indiana UP, 1991.

DeKoven, Marianne. "Modernism and Gender." Cambridge Companion to Modernism: Second Edition. Michael Levenson, ed. Cambridge: Cambridge UP, 2011. 212-231.

Didi-Huberman, Georges. Invention of Hysteria: Charcot and the Photographic Iconography of the Salpêtrière. Boston: MIT Press, 2004.

Angles, 6 | 2018 
Schoenbach, Lisi. "Introduction: Pragmatic Modernism." Pragmatic Modernism. Oxford: Oxford UP, 2012. 1-16.

Elliott, Bridget, and Jo-Ann Wallace. Women Writers and Artists: Modernist (Im)Positionings. London: Routledge, 1994.

Jameson, Frederic. The Modernist Papers. London: Verso, 2007.

Knopp, Sherron E. “'If I Saw You Would You Kiss Me?': Sapphism and the Subversiveness of Virginia Woolf's Orlando." Modern Language Association vol. 103, No. 1 (1988): 24-34. DOI:

$10.2307 / 462459$

Lanser, Susan Sniader. “Speaking in Tongues: 'Ladies Almanack' and the Language of Celebration.” Frontiers: A Journal of Women Studies. vol. 4, No. 3 (1979): 39-46. DOI: 10.2307/3346147 Levenson, Michael, ed. Cambridge Companion to Modernism: Second Edition. Cambridge: Cambridge UP, 2011.

Majumdar, Robin and Allen McLaurin, eds. Virginia Woolf: The Critical Heritage. London: Routledge \& Kegan Paul Ltd, 1975.

Marcus, Jane. "Mousemeat: Contemporary Reviews of Nightwood." Silence and Power: A Reevaluation of Djuna Barnes. Mary Lynn Broe, ed. Carbondale: Southern Illinois UP, 1991. 195-204.

McDonald, Gail. Learning to Be Modern: Pound, Eliot, and the American University. Oxford: Oxford UP, 1993.

Nair, Sashi. Secrecy and Sapphic Modernism: Reading Romans à Clef Between the Wars. New York: Palgrave MacMillan, 2012.

Nicholls, Peter. Modernisms. New York: Palgrave Macmillan, 2009.

Pease, Allison. "Modernism and Mass Culture." Cambridge Companion to Modernism: Second Edition. Ed. Michael Levenson. Cambridge: Cambridge UP, 2011. 197-211.

Suleiman, Susan Rubin. “A Double Margin: Reflections on Women Writers and the Avant-Garde in France.” Yale French Studies, No. 75 (1988): 148-172. DOI: 10.2307/2930312

West, Paul. Afterword. “The Havoc of the Nicety.” Ryder. By Djuna Barnes. 1928. 2nd edition. Normal: Dalkey Archive Press, 1990. 243-250.

Woolf, Virginia. Orlando: A Biography. 1928. Orlando: Harcourt Inc., 1973.

Woolf, Virginia. A Change of Perspective: The Letters of Virginia Woolf: Volume III: 1923-1928. Nigel Nicolson, ed. London: The Hogarth Press, 1977.

Woolf, Virginia. The Diary of Virginia Woolf: Volume III: 1925-1930. Anne Olivier Bell, ed. London: The Hogarth Press, 1980

\section{NOTES}

1. Outside of North America and Western Europe, there were geographical variations in what constituted experimental work. Recent research into global modernisms, Asian and African modernisms for example, challenges the Anglophone conception of modernism as the default.

2. Within the field of modernist studies, alternative modernisms are now widely accepted. Michael Levenson writes in the Cambridge Companion to Modernism: "It is so tempting to make the many Modernisms into one thing, and then to place that one thing into a single chapter within a 
tidy narrative" (Levenson 2011: 4). Yet outside of academic circles, these popular perceptions of modernism persist.

3. Orlando is intimately biographical. Woolf wrote to Sackville-West: "I've lived in you all these months-coming out, what are you really like? Do you exist? Have I made you up?" and "I'm so engulfed in Orlando I can think of nothing else... I make it up in bed at night, as I walk the streets, everywhere... I have never more wanted to see you than I do now" (Woolf 1977: 264, 430).

4. Here I am referring to the tradition of treating female sexuality as a disorder, e.g. the history of hysteria, as discussed in Didi-Huberman (2004).

\section{ABSTRACTS}

The following paper posits that High Modernism regards experimental literature purely in terms of form, not content; and how this regard is rooted in the gendering of literature i.e. masculine signaling "experimental" and feminine signaling "traditional." As a result, the modernist canon is rooted in the exclusion of the other, notably texts that disrupt conservative views on gender and sexuality. I show how, contrary to popular belief, Djuna Barnes's Ladies Almanack and Virginia Woolf's Orlando are two experimental modernist texts, both in terms of their "archaic" language and in terms of their sexual politics. The fact that both texts are indeed experimental forces Modernism to reexamine its exclusionary practices and how it defines experimentalism.

Cet article cherche à montrer que le «high modernism» a toujours perçu la littérature expérimentale seulement d'un point de vue formel, sans tenir compte du contenu ; mais cette approche est intrinsèquement sexiste, opposant le masculin «expérimental» au féminin «traditionnel». Par ailleurs, l'œuvre moderniste est enracinée dans l'exclusion de l'autre, notamment les textes qui défient les perspectives conservatrices sur le genre et la sexualité. Cette contribution montre qu'au contraire Ladies Almanack de Djuna Barnes et Orlando de Virginia Woolf sont des textes expérimentaux par leur langage, soi-disant « archaïque », mais aussi par leur traitement de la sexualité. Cela oblige le Modernisme à réexaminer ses pratiques d'exclusion et, partant, sa définition de l'expérimentalisme.

\section{INDEX}

Mots-clés: Barnes Djuna, Woolf Virginia, littérature, modernisme, genre, sexualité, saphisme Keywords: Barnes Djuna, Woolf Virginia, literature, Modernism, gender, sexuality, Sapphism

\section{AUTHOR}

\section{ELAINE HSIEH CHOU}

Elaine Hsieh Chou studied English literature at the University of California Irvine, the University of Lorraine and La Sorbonne Nouvelle Paris 3. She is currently completing an MFA degree in fiction at New York University. Contact: http://www.elainehsiehchou.com/ 